\title{
Hydrologic Characterizaton of the Unconfined Aquifer at the General Motors Harrison Division Plant, Tuscaloosa, Alabama
}

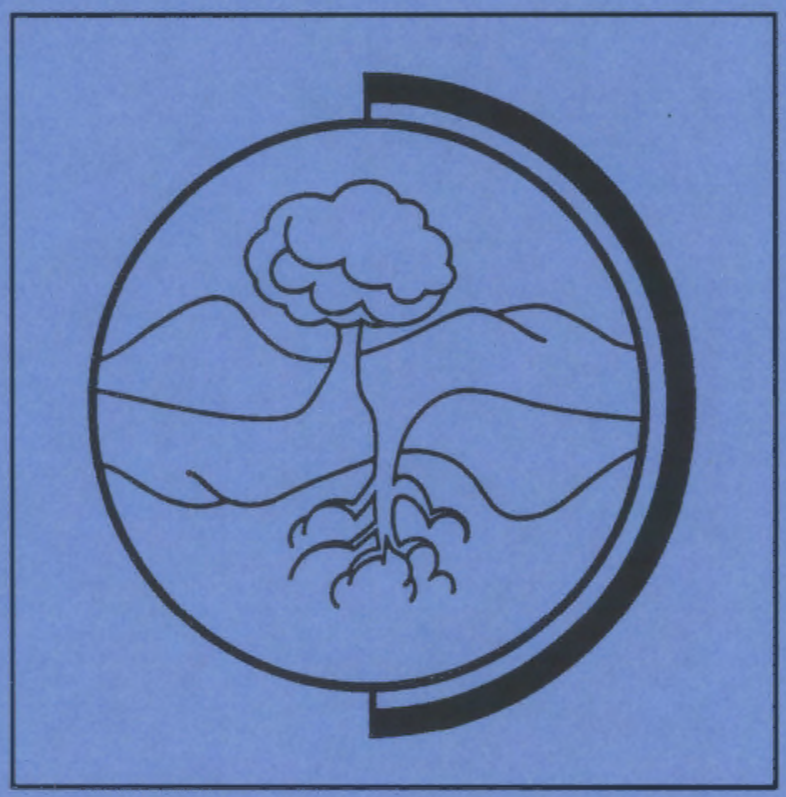

March 1991

Prepared for the U.S. Department of Energy

Contract DE-AC06-76RLO 1830

Pacific Northwest Laboratory

Operated for the U.S. Department of Energy

by Battelle Memorial Institute 


\title{
DISCLAIMER
}

This report was prepared as an account of work sponsored by an agency of the United States Government. Neither the United States Government nor any agency thereof, nor Battelle Mernorial Institute, nor any of their employees, makes any warranty, expressed or implied, or assumes any legal liability or responsibility for the accuracy, completeness, or usefulness of any information, apparatus, product, or process disclosed, or represents that its use would not infringe privately owned rights. Reference herein to any specific commercial product, process, or service by trade name, trademark, manufacturer, or otherwise does not necessarily constitute or imply its endorsement, recommendation, or favoring by the United States Government or any agency thereof, or Battelle Memorial Institute. The views and opinions of authors expressed herein do not necessarily state or reflect those of the United States Government or any agency thereof.

\author{
PACIFIC NORTHWEST LABORATORY \\ operated by \\ BATTELLE MEMORIAL INSTITUTE \\ for the \\ UNITED STATES DEPARTMENT OF ENERGY \\ under Contract DE-ACO6-76RLO 1830
}

\author{
Printed in the United States of America \\ Available to DOE and DOE contractors from the \\ Office of Scientific and Technical Information, P.O. Box 62, Oak Ridge, TN 37831; \\ prices available from (615) 576-8401. FTS 626-8401. \\ Available to the public from the National Technical Information Service, \\ U.S. Department of Commerce, 5285 Port Royal Rd., Springfield, VA 22161.
}


PNL-7641

UC-202

HYDROLOGIC CHARACTERIZATION OF THE UNCONFINED AQUIFER AT THE GENERAL MOTORS HARRISON DIVISION PLANT, TUSCALOOSA, ALABAMA
S. H. Hall
D. R. Newcomer
S. P. Luttrell

March 1991

Prepared for the U.S. Department of Energy under Contract DE-AC06-76RLO 1830

Pacific Northwest Laboratory Richland, Washington 99352 



\section{FOREWORD}

Seasonal thermal energy storage (STES) involves storing thermal energy, such as winter chill, summer heat, and industrial waste heat, for future use in heating and/or cooling buildings or for industrial processes. Widespread development and implementation of STES would significantly reduce the need to generate primary energy in the U.S. Recent data indicates that STES is technically suitable for providing $5 \%$ to $10 \%$ of the nation's energy, with major contributions in the commercial and industrial sectors and in district heating and cooling applications.

Aquifer themal energy storage (ATES) is predicted to be the most costeffective technology for seasonal storage of low-grade thermal energy. Approximately $60 \%$ of the U.S. is underlain by aquifers that are potentially suitable for underground energy storage. Chill ATES has the potential to substantially reduce energy consumption and, especially, summer peak cooling electrical demand. However, the geohydrologic environment that the system will use is a major element in system design and operation, and this environment must be characterized for development of efficient energy recovery.

This report describes additional aquifer characterization of a site proposed for an ATES chill system at the General Motors Harrison Division Plant in Tuscaloosa, Alabama. The aquifer characterization work was conducted by the U.S. Department of Energy's Pacific Northwest Laboratory (Seasonal Thermal Energy Storage Program) in cooperation with the University of Alabama as part of efforts to assess the use of chill ATES for industrial cooling. The Pacific Northwest Laboratory is operated by Battelle Memorial Institute for the Department of Energy under contract DE-AC06-76RLO 1830. The project was managed by Dr. C. Everett Brett, Director of the University of Alabama Natural Resources Center. 


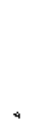




\section{SUMMARY}

General Motors (GM) is studying the feasibility of aquifer themal energy storage (ATES) for air conditioning at their Harrison Division plant located in Tuscaloosa, Alabana. Pacific Northwest Laboratory (PNL) has assisted in this effort by conducting field tests to measure the hydraulic properties of the proposed ATES well field, which will be within the unconfined aquifer and adjacent to the GM plant.

In May 1989, PNL performed hydrologic and geochemical tracer tests within the proposed well field. Results showed that in the vicinity of the test we11, transmissivity was $2000 \mathrm{ft}^{2} / \mathrm{d}$, effective aquifer thickness was $50 \mathrm{ft}$, effective porosity was $6.2 \%$, hydraulic gradient was 0.005 , and seepage velocity was $3.2 \mathrm{ft} / \mathrm{d}$.

In October 1990, PNL performed a similar series of tests at a newly constructed well within the well field and $272 \mathrm{ft}$ from the test well of the previous year. This second test series was expanded to include measuring specific capacity and investigating the vertical distribution of flow with in the aquifer. Specific objectives were to determine the injection capacity of the aquifer and to examine efficiency of the well design.

Transmissivity was 2300 to $2600 \mathrm{ft}^{2} / \mathrm{d}$, effective aquifer thickness was $58 \mathrm{ft}$, effective porosity was 6.0 to $8.0 \%$, hydraulic gradient was 0.0047 , and seepage velocity was 3.1 to $2.7 \mathrm{ft} / \mathrm{d}$. Injection capacity, based on a stepinjection test, was approximately $17 \mathrm{gpm} / \mathrm{ft}$ and was independent of flow rate within the experimental range 90 to $338 \mathrm{gpm}$. In the withdrawal mode, the specific capacity at very low flow was also approximately $17 \mathrm{gpm}$, decreasing to $11 \mathrm{gpm} / \mathrm{ft}$ at $225 \mathrm{gpm}$ (based on drawdown measurements at the May 1989 test we11, which was used as the supply well for the above step-injection test).

Maxinum hydraulic conductivity occurred within the uppermost $20 \mathrm{ft}$ of saturated sediments, which consisted of well-sorted sand. Below the sand, sorting was progressively poorer with depth, and hydraulic conductivity decreased smoothly. At the base of the aquifer, hydraulic conductivity was less than $10 \%$ of that of the uppermost $20 \mathrm{ft}$. 


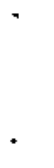




\section{ACKNOWLEDGMENTS}

We are grateful to Professor C. Everett Brett, Director of the University of Alabama Natural Resources Center, and to Mr. Yeong K. Song, University of Alabama College of Engineering, for their aid in conducting the field experiments. We also thank Dr. Brett for supplying descriptions of the sediment samples.

This work was supported by the Pacific Northwest Laboratory Seasonal Thermal Energy Storage Program. 


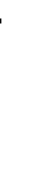




\section{CONTENTS}

FOREWORD ................................ SUMMARY ....................... v ACKNOWLEDGMENTS ................................. vii 1.0 INTRODUCTION . . . . . . . . . . . . . . . . 1.1 2.0 STRATIGRAPHY AND GRADIENT ANALYSIS . . . . . . . . . . 2.1 3.0 STEP-INJECTION TEST . . . . . . . . . . . . . 3.1

3.1 WELL DESIGN AND DEVELOPMENT . . . . . . . . . . 3.1

3.2 EXPERIMENTAL $\ldots \ldots \ldots \ldots \ldots . \ldots \ldots . \ldots \ldots$

3.3 SPECIFIC CAPACITY . . . . . . . . . . . 3.3

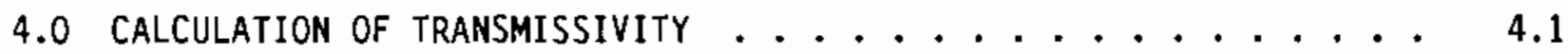

5.0 DRIFT-AND-PUMPBACK TEST $\ldots \ldots \ldots \ldots . \ldots \ldots$

6.0 POINT-dilution TEST . . . . . . . . . . . . . 6.1

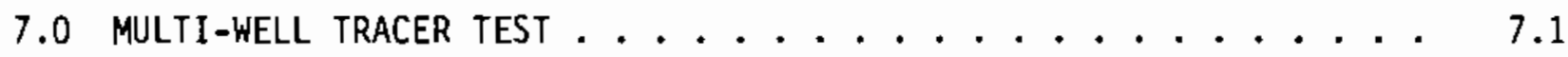

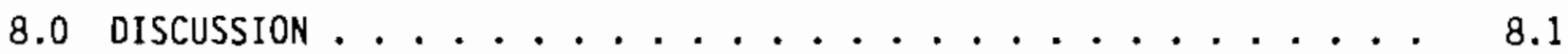

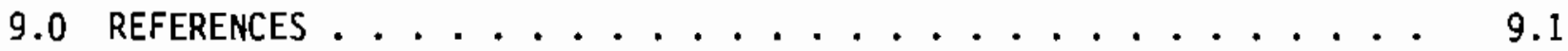




\section{FIGURES}

1.1 Well Locations and Water-Level Contours at the General Motors

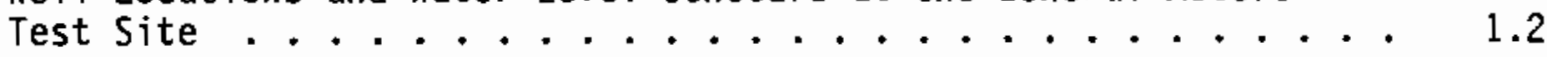

2.1 Well Construction and Sediment Composition at Well \#10 . . . . 2.2

3.1 Water Level Versus Time During the Step-Injection Test . . . . . 3.2

3.2 Drawdown Versus Time at the Supply Well During the Step-Injection

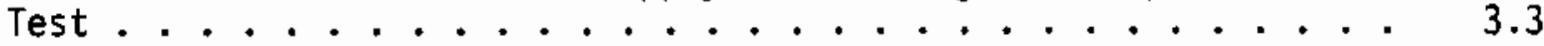

3.3 Normalized Water-Level Change Versus Injection Rate During the Step-Injection Test ................... 3.4

3.4 Normalized Water-Level Change Versus Discharge Rate at the Supply Well During the Step-Injection Test . . . . . . . . 3.5

4.1 Drawdown Versus Time During the Pumpback Phase of the Drift-andPumpback Test ................... 4.1

5.1 Bromide Concentration Versus Time During Tracer Pumpback . . . . 5.2

6.1 Bromide Concentration Versus Time During the Point-Dilution Test for Three Representative Depths .......... 6.2

6.2 Relative Ground-Water Flow as a Function of Depth ....... 6.3 


\subsection{INTRODUCTION}

General Motors (GM) is studying the feasibility of aquifer thermal energy storage (ATES) for air conditioning at their Harrison Division plant located in Tuscaloosa, Alabama. In the design of this ATES installation, ground water will be circulated between plant heat exchangers and a well field installed in an aquifer. Chilled water produced in the plant during cool months will be stored in the aquifer. The insulating properties of the aquifer will maintain the temperature of the injected water below the natural ambient temperature of the aquifer. Months later, the stored water will be withdrawn from the aquifer to serve as a heat sink when it is once again passed through the heat exchangers.

Designing an efficient well field for an ATES installation requires a thorough understanding of aquifer characteristics. These characteristics include geometry, hydraulic conductivity, effective porosity, ground-water flow direction and velocity, and specific capacity during injection and withdrawal. Field studies have been conducted by Pacific Northwest Laboratory $(P N L){ }^{(a)}$ to determine these characteristics for the unconfined aquifer at the GM site. Figure 1.1 shows the GM test site. PNL staff (Luttrell et al. 1989) conducted a series of tests at Well \#4 in May 1989. This report describes a similar series of tests conducted at Well \#10 in October 1990.

Luttrell et al. (1989) found transmissivity to be $2000 \mathrm{ft}^{2} / \mathrm{d}$ in the vicinity of Well \#4, based on a constant-discharge pumping test. Drillers' logs indicated an effective aquifer thickness of $50 \mathrm{ft}$ in the vicinity of this well, so hydraulic conductivity was calculated to be $40 \mathrm{ft} / \mathrm{d}$. Water-level measurements at Wells \#1 through \#9 indicated a hydraulic gradient of 0.005 , with ground-water flow toward the southwest. Following water-level recovery from the pumping test conducted at Well \#4, Luttrell et al. (1989) performed a drift-and-pumpback tracer test at that well. Using lithium bromide as a ground-water tracer, they conducted this test in the manner described by Leap and Kaplan (1988). By combining the test results from the tracer test, the

(a) Operated for the U.S. Department of Energy by Battelle Memorial Institute. 


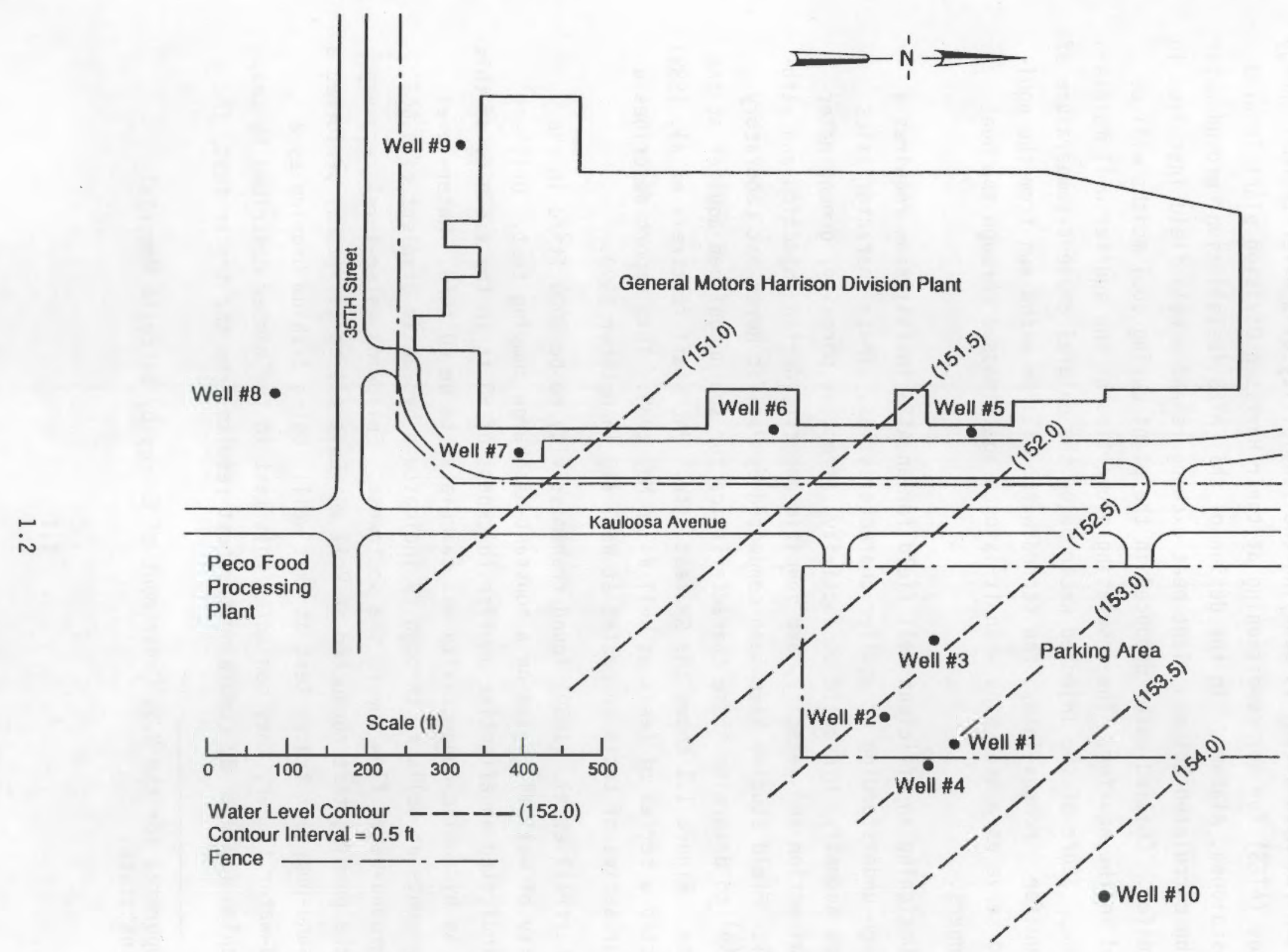

FIGURE 1.1. Well Locations and Water-Level Contours at the General Motors Test Site 
pumping test, and the gradient analysis, Luttrell et al. (1989) calculated ground-water seepage velocity and effective porosity, which were approximately $3.2 \mathrm{ft} / \mathrm{d}$ and $6.2 \%$. The calculated velocity was partially verified with a twowell tracer test, conducted under natural gradient between wells \#4 and \#2 (Hall et al. 1990). Based on this test, a lower bounding limit of $3.0 \mathrm{ft} / \mathrm{d}$ was established for the velocity.

The purpose of the new test series described in this report was threefold. First, repeating the experiments reported by Luttrell et al. (1989) at a new location (We11 \#10) provided additional field data by which to judge the variability of aquifer hydraulic properties within the proposed ATES well field. Second, the engineering design of the ATES installation required field verification of the injection capacity of the aquifer. Third, the new test series offered the opportunity to investigate the vertical distribution of flow velocities within the aquifer. Well \#10, completed in 0ctober 1990, lies $272 \mathrm{ft}$ northeast of Well \#4 (see Figure 1.1). The test series was organized as follows:

1. Water-level measurements were made at each of the 10 wells to verify the estimates of gradient and flow direction provided by Luttrell et al. (1989) and to extend the water-table map to include well $\# 10$. The results of the measurements are presented in Section 2.0.

2. A step-injection test, described in Section 3.0, was performed at Well 10. Well \#4 was used as the supply well for this test.

3. Following recovery from the step-injection test, a drift-andpumpback test (described in Section 5.0) was initiated at Well \#10 by injecting a lithium bromide tracer solution into the well.

4. The tracer injection was treated as a point-dilution test as described by Kearl et al. (1988). Bromide concentration as a function of both depth and time in the well bore was monitored using a down-hole ion-selective electrode. This test is described in Section 6.0.

5. After a suitable residence time, the drift-and-pumpback test was completed by pumping the test well to recover the bromide tracer. Bromide concentration of the discharge stream was monitored using an ion-selective electrode.

6. Drawdown at the test well was monitored during tracer pumpback to provide an estimate of transmissivity (as discussed in Section 4.0). 
7. Following recovery from the tracer pumpback, a multi-well tracer test, conducted under natural gradient, was initiated by injecting a second lithium bromide tracer solution into the test well. This test is described in Section 7.0. Down-gradient wells will be periodically sampled and analyzed for both lithium and bromide. This is necessarily a long-term test, and results will be reported subsequently.

The sections that follow discuss stratigraphy, well construction, experimental conditions, test results, and data analysis. 


\subsection{STRATIGRAPHY AND GRADIENT ANALYSIS}

The unconfined aquifer at the GM site is within the unconsolidated sands, gravels, and clays of the Coker formation and/or recent terrace gravels that overlie the Pottsville formation. The Pottsville formation consists of shales and limestone of low permeability. Figure 2.1 illustrates well construction and sediment composition at Well \#10. The total thickness of the sediments overlying the Pottsville formation at the well is approximately $82 \mathrm{ft}$. The saturated thickness of the sediments is $58 \mathrm{ft}$.

Effective aquifer thickness is somewhat varied within the proposed ATES well field. Luttrell et al. (1989) showed that the saturated thickness of sediments above the Pottsville formation at Well \#4 may be as great as $70 \mathrm{ft}$. However, they noted that the presence of a compact, low-permeability clay unit at the base of the sediments limits the effective thickness of the aquifer to $50 \mathrm{ft}$ in the vicinity of that well.

Luttrell et al. (1989) also showed that the uppermost stratum at the GM site consists of compact clay but that this stratum is generally several feet above water table. Figure 2.1 indicates that this clay extends to Well \#10. Luttrell et al. (1989) also noted an apparently extensive clay layer within the aquifer that may divide the saturated sediments into two distinct hydrostratigraphic units, the lower being confined. This layer was not observed at Well \#10.

These observations indicate that the saturated thickness of sediments that can effectively contribute to ground-water flow is greater at Well \#10 than at Wel1 \#4. Thus, if the hydraulic conductivity of the aquifer sediments at the two wells is assumed to be essentially the same, one can reasonably expect a somewhat higher hydraulic gradient near Well \#4 than at Well \#10. The water-level contours included in Figure 1.1 confirm this expectation. These contours are based on data collected October 19, just before the stepinjection test, and they were prepared using steel-tape water-level measurements and surveyed well-casing elevations from all 10 wells. 
WELL CONSTRUCTION

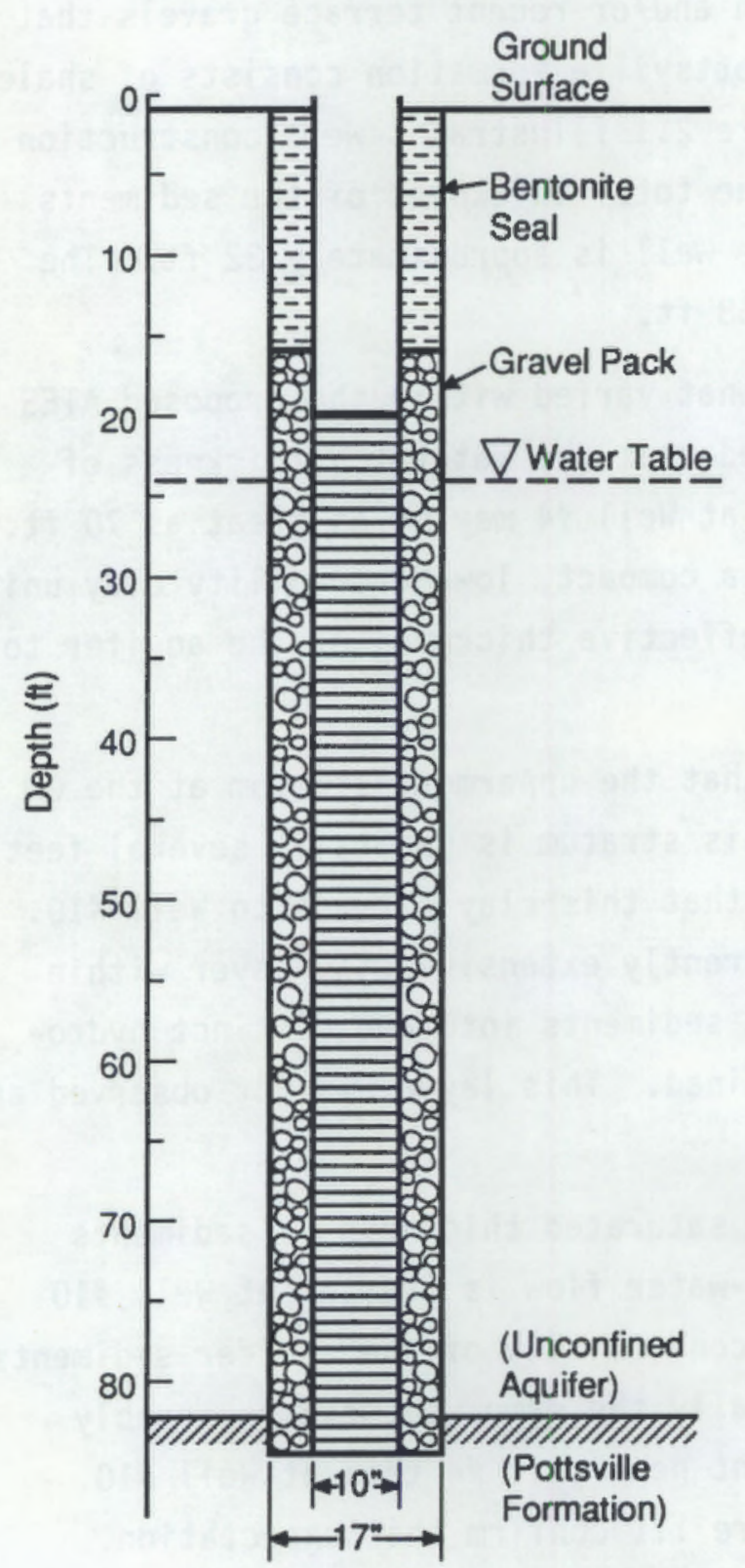

SEDIMENT COMPOSITION

Depth Interval $\%$ Gravel \% Sand \% Clay (from surface)

\begin{tabular}{|c|c|c|c|}
\hline 0 & 60 & 40 & $0-5$ \\
\hline 10 & 90 & 0 & $5-10$ \\
\hline 0 & 90 & 10 & $10-15$ \\
\hline$<5$ & 80 & 20 & $15-20$ \\
\hline 0 & 100 & 0 & $20-25$ \\
\hline 0 & 100 & 0 & $25-30$ \\
\hline 0 & 100 & 0 & $30-35$ \\
\hline 0 & 100 & 0 & $35-40$ \\
\hline 0 & 100 & 0 & $40-45$ \\
\hline 10 & 90 & 0 & $45-50$ \\
\hline 80 & 20 & 0 & $50-55$ \\
\hline 95 & 0 & 5 & $55-60$ \\
\hline 95 & 0 & 5 & $60-65$ \\
\hline 80 & 0 & 20 & $65-70$ \\
\hline 75 & 5 & 20 & $70-75$ \\
\hline 70 & 10 & 20 & $75-80$ \\
\hline
\end{tabular}

FIGURE 2.1. Well Construction and Sediment Composition at Well \#10

The contours in Figure 1.1 confirm both the flow direction and the gradient reported by Luttrell et al. (1989) for Well \#4 and its immediate vicinity. The gradient in the vicinity of Well \#10 is 0.0047 . 


\subsection{STEP-INJECTION TEST}

This test was conducted to determine the specific injection capacity of the aquifer near Well \#10. Well \#4, $272 \mathrm{ft}$ southwest of Well \#10, was used to supply ground water for injection. Water-level data collected from Well \#4 during this test are treated as a concurrent step-drawdown test, and a similar data analysis has been applied. The analysis has assumed negligible mutual hydrautic interference between the wells.

\subsection{WELL DESIGN AND DEVELOPMENT}

Well \#10 was drilled using the mud rotary method and a 17-in. diameter bit. The well was drilled through the unconsolidated sediments and 2 to $3 \mathrm{ft}$ into the underlying Pottsville formation. The well, completed on October 2 , was constructed with slotted polyvinyl chloride (PVC) well casing, 10-in. ID and having 0.032-in. openings, except for the upper $20 \mathrm{ft}$ of casing, which was not slotted. The packing material was moderately rounded screened gravel with a nominal diameter of $0.09 \mathrm{in}$. The gravel pack extended from total depth to approximately $4 \mathrm{ft}$ above the junction of slotted and unslotted casing. Bentonite pellets were used to seal the annular space from the top of the gravel pack to the ground surface.

Upon completion, the well was developed by air-lift pumping and "acid" treatment (sodium acid pyrophosphate). The well was further developed by $12 \mathrm{~h}$ of pumping on October 16 at an estimated 350 to $400 \mathrm{gpm}$.

Well \#4, completed in 1984 and also fully penetrating, was also constructed using 17-in. mud rotary drilling and slotted 10-in. casing. Details are unavailable on development history, casing material, slot size, and nominal size of the packing gravel.

\subsection{EXPERIMENTAL}

The step-injection test was conducted on October 19 beginning at 1222 hours. At 1812 hours, the pump was stopped and the recovery was 
monitored. The total duration of pumping was $350 \mathrm{~min}$. Recovery from injection was judged complete on October 20 at 0522 hours, 670 min after the pump was shut off.

Water levels in both the test well and the supply well were monitored with down-hole pressure transducers. The discharge rate from the supply well was measured with a pitot tube flowneter calibrated in the field by timing discharge into a 55-gal barrel. The pipeline from the supply well to the test well was 4-in. PVC, and it terminated $50 \mathrm{ft}$ below the top of the well casing at Well \#10, approximately $26 \mathrm{ft}$ below static water level.

During the test, the injection rate was incremented in 6 steps, ranging from 90 to $338 \mathrm{gpm}$. The duration of the flow steps ranged from 15 to $34 \mathrm{~min}$, except for the final step, which was sustained for approximately $4 \mathrm{~h}$. Figures 3.1 and 3.2 illustrate the water-level responses in Wells $\# 10$ and \#4. Both figures show a water-level spike 63 min into the test. These spikes were caused by a 2 -min power failure of the generator.

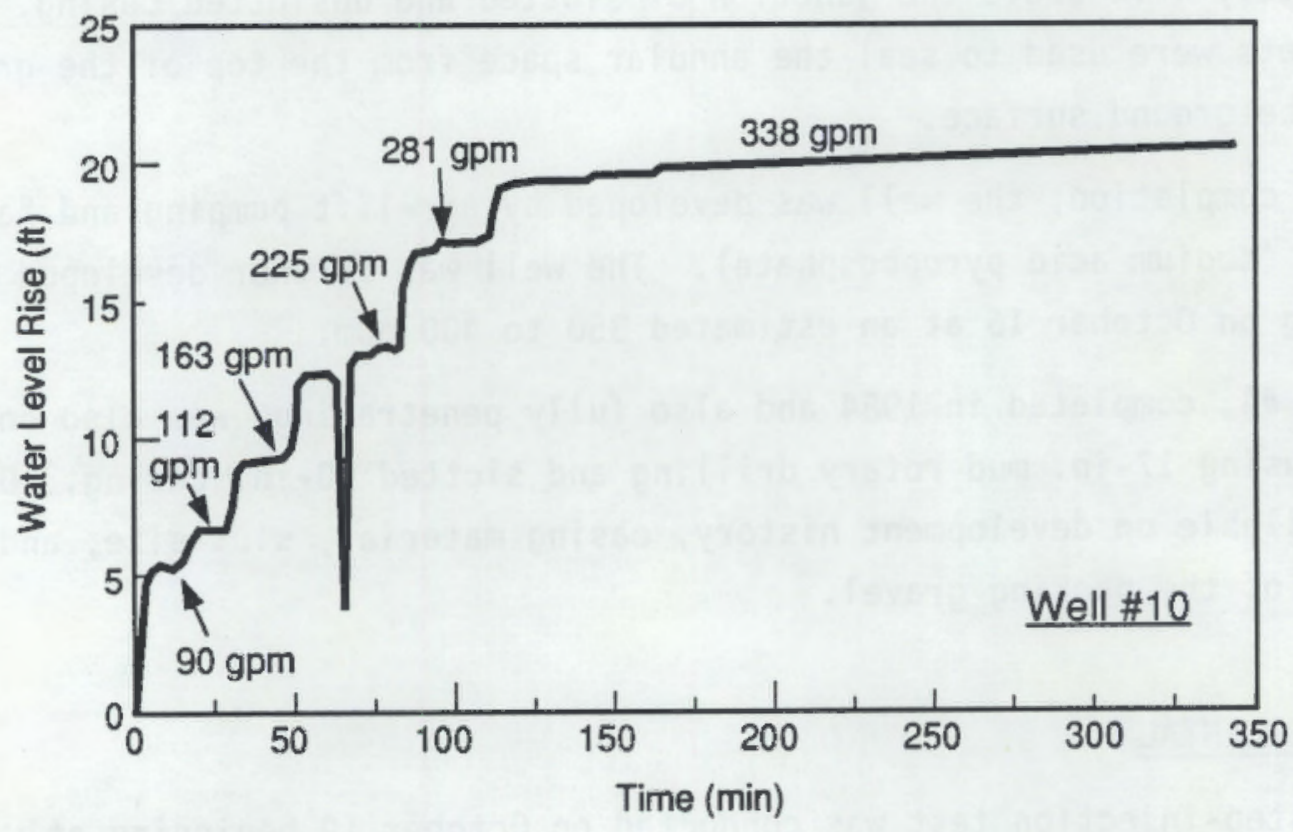

FIGURE 3.1. Water Level Versus Time During the StepInjection Test 


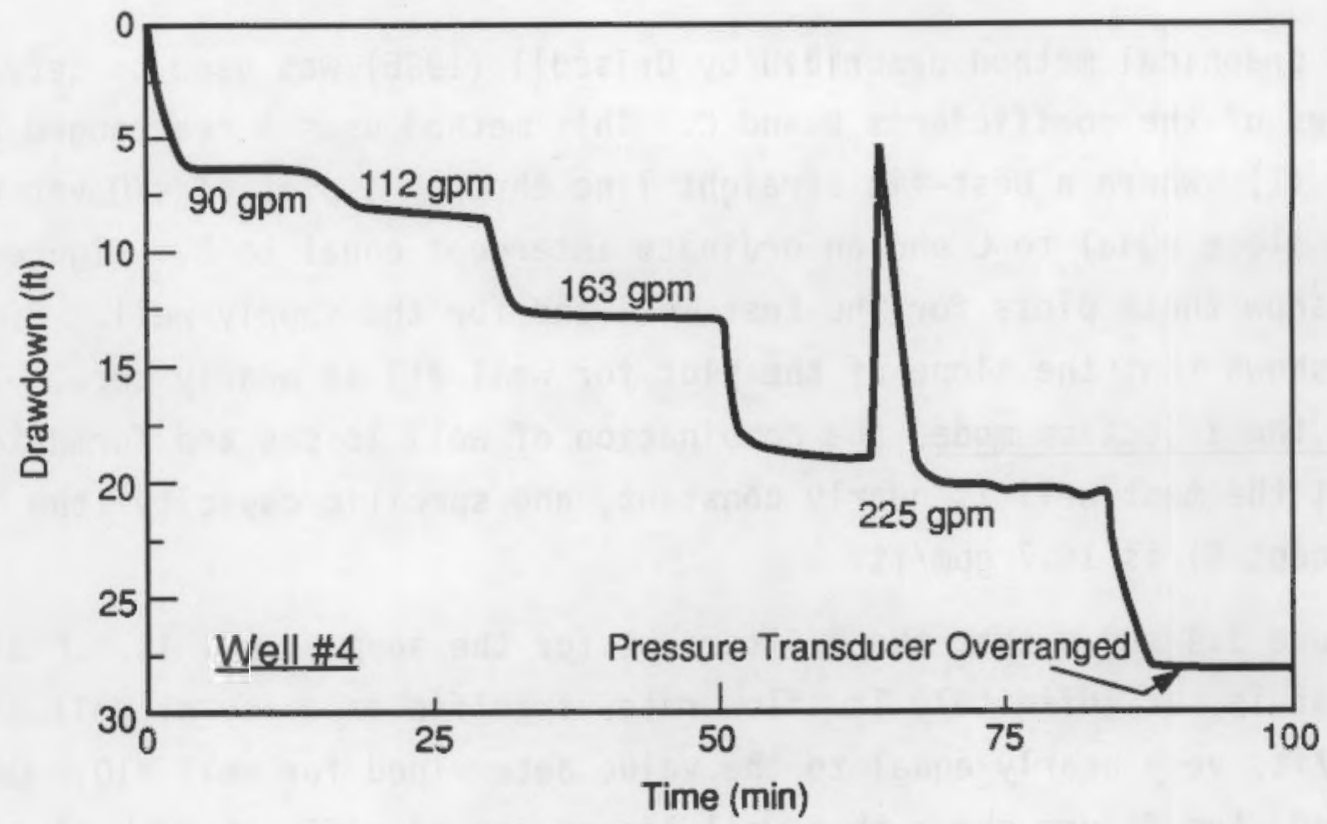

FIGURE 3.2. Drawdown Versus Time at the Supply well During the Step-Injection Test

The pressure-response range of the transducer in the supply well was exceeded after $88 \mathrm{~min}$, so that only the first four drawdown steps are available for analysis.

\subsection{SPECIFIC CAPACITY}

Specific capacity for each well was determined using the method described by Jacob (1946), where the change in water level is expressed as a function of flow as follows:

$$
s=B Q+C Q^{2}
$$

$$
\text { where } \begin{aligned}
s & =\text { drawdown, in } \mathrm{ft} \\
Q & =\text { flow rate, in } \mathrm{gpm} \\
B & =\text { formation loss coefficient } \\
C & =\text { well loss coefficient. }
\end{aligned}
$$


The graphical method described by Driscoll (1986) was used to determine the values of the coefficients $B$ and $C$. This method uses a rearranged form of Equation (1), where a best-fit straight line through a plot of $s / Q$ versus $Q$ yields a slope equal to $C$ and an ordinate intercept equal to $B$. Figures 3.3 and 3.4 show these plots for the test well and for the supply well. Figure 3.3 shows that the slope of the plot for well \#10 is nearly zero. Therefore, in the injection mode, the combination of well losses and formation losses at the test well is nearly constant, and specific capacity (the inverse of intercept B) is $16.7 \mathrm{gpm} / \mathrm{ft}$.

Figure 3.4 shows that the B intercept for the supply well is $0.058 \mathrm{ft} /$ gpm. That is, at infinitely low flow rate, specific capacity at Well \#4 is $17.2 \mathrm{gpm} / \mathrm{ft}$, very nearly equal to the value determined for well \#10. On the other hand, the figure shows that well losses are significant in Well \#4, increasing significantly as discharge increases.

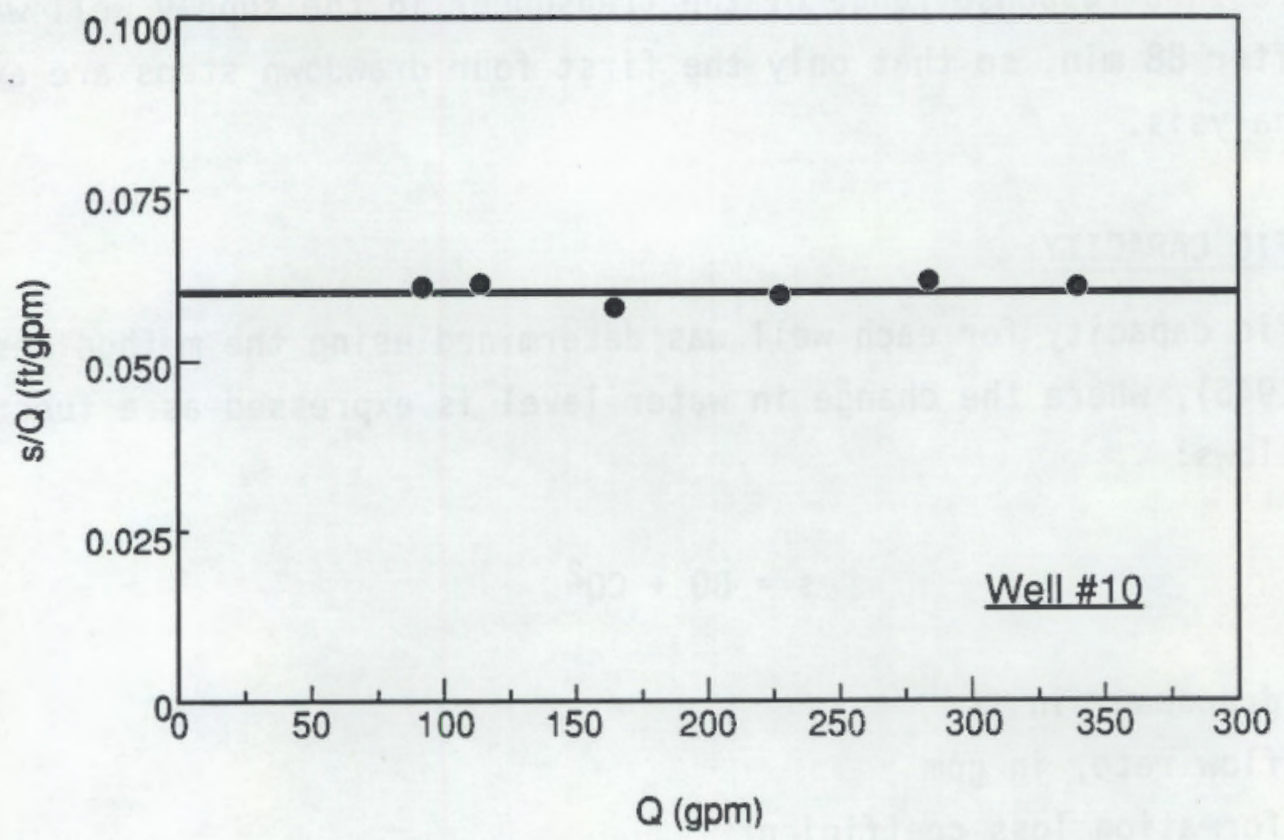

FIGURE 3.3. Normalized Water-Level Change Versus Injection Rate During the Step-Injection Test 


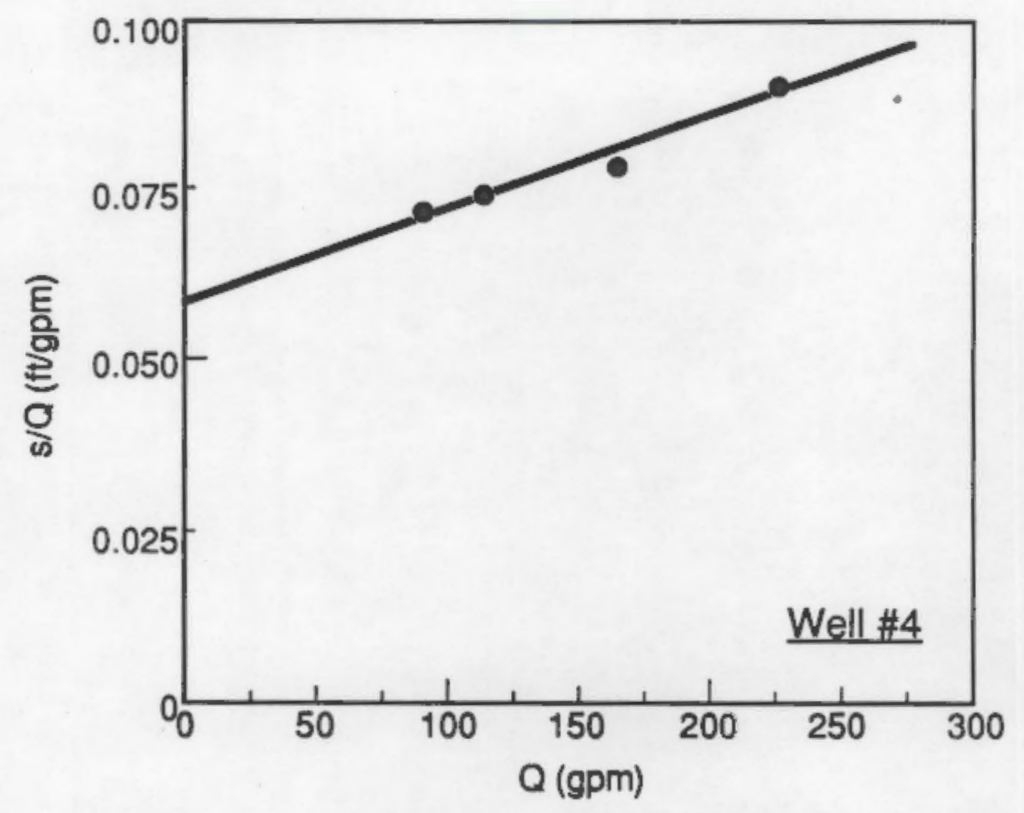

FIGURE 3.4. Normalized Water-Level Change Versus Discharge Rate at the Supply Well During the Step-Injection Test 



\subsection{CALCULATION OF TRANSMISSIVITY}

The transmissivity of Well \#10 may be estimated by using observed specific capacity. The equation used to relate specific capacity to transmissivity, as presented by Walton (1970), is

$$
Q / S=T /\left(264 \log \left(T t / 2693 S r^{2}\right)-65.5\right)
$$

where $T=$ transmissivity, in $\mathrm{gpd} / \mathrm{ft}$

$Q=$ discharge, in $\mathrm{gpm}$

$s=$ drawdown, in $\mathrm{ft}$

$S=$ storage coefficient

$r=$ effective radius of well, in $\mathrm{ft}$

$t=$ time since pumping began, in min.

For Equation (2), experimental data are taken from drawdown measurements collected during the withdrawal phase of the drift-and-pumpback test, as shown in Figure 4.1. At $360 \mathrm{~min}$, observed drawdown at $60 \mathrm{gpm}$ was $4.2 \mathrm{ft}$, for a

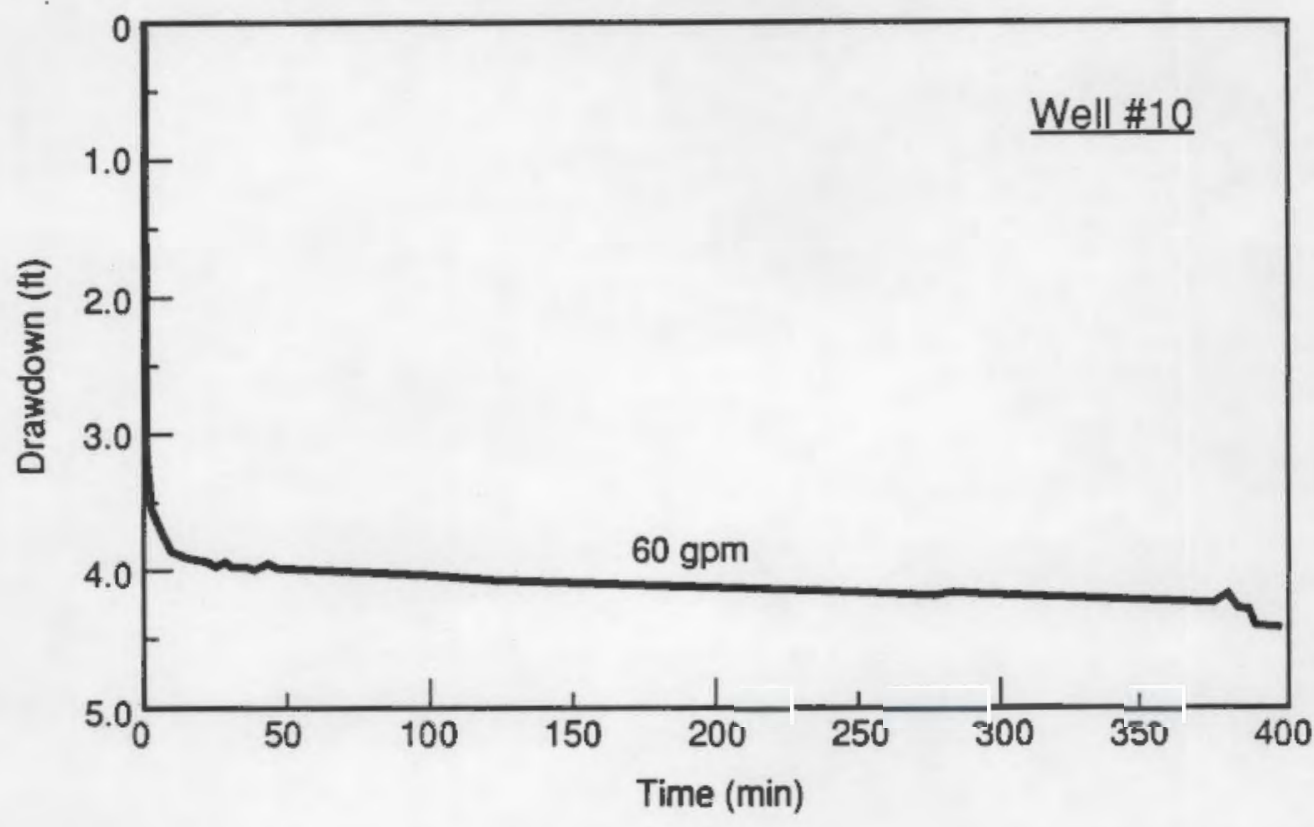

FIGURE 4.1. Drawdown Versus Time During the Pumpback Phase of the Drift-and-Pumpback Test 
calculated specific capacity of $14.3 \mathrm{gpm} / \mathrm{ft}$. Because the supply well and the test well were constructed similarly, well losses at Well \#10 are assumed to be the same as at Well \#4. Therefore, the plot shown in Figure 3.4 can be used to correct observed drawdown for well losses at Well \#10. Figure 3.4 shows that at $60 \mathrm{gpm}$ drawdown attributable to well losses is $0.007 \mathrm{ft} / \mathrm{gpm}$. Subtracting this drawdown from $0.070 \mathrm{ft} / \mathrm{gpm}$ (the inverse of $14.3 \mathrm{gpm} / \mathrm{ft}$ ) yields $0.063 \mathrm{ft} / \mathrm{gpm}$ for Well \#10, or a specific capacity for the aquifer (independent of well losses) of $15.9 \mathrm{gpm} / \mathrm{ft}$. The effective well radius is taken as $0.71 \mathrm{ft}$, one-half the diameter of the uncased borehole. The best estimate for the storage coefficient is taken here as the effective porosity, derived from the results of the drift-and-pumpback test (see below). However, the effective porosity is a function of hydraulic conductivity, and therefore of transmissivity, so calculating this value requires several iterations between Equation (2) and Equation (3) (below). With this approach, the calculated transmissivity is $2600 \mathrm{ft}^{2} / \mathrm{d}$, and the hydraulic conductivity is $45 \mathrm{ft} / \mathrm{d}$. 


\subsection{DRIFT-AND-PUMPBACK TEST}

On October 20, the drift-and-pumpback tracer test was initiated by injecting a solution containing $200 \mathrm{~g}$ lithium bromide into Well \#10 at 1032 hours. To inject the bromide, a 5/8-in. ID hose, open at both ends, was suspended in the well to a depth of $81 \mathrm{ft}$. The hose was weighted with a plastic jug having a radius of approximately $7 \mathrm{in.}$ Gravel was added to the jug as ballast. The contained volume of the hose, from water table to the $81-\mathrm{ft}$ depth, was $0.95 \mathrm{gal}$. That volume of water, therefore, was used to dissolve the lithium bromide. The solution was poured into the top of the hose, displacing the well water. The hose was then slowly withdrawn from the well, leaving the tracer solution in the well, evenly distributed vertically. The jug used to weight the hose also served to mix the solution in the well bore as the hose was withdrawn. A downhole bromide ion-selective electrode (described in Section 6.0) was used to confirm that the tracer was evenly distributed. The bromide concentration in the well was approximately $200 \mathrm{mg} / \mathrm{L}$ immediately after emplacement.

The tracer was allowed to drift into the aquifer under natural gradient until October 23 at 0926 hours, when pumpback at the rate of $60 \mathrm{gpm}$ was started. Total drift time prior to pumpback was $4254 \mathrm{~min}$. The bromide concentration of the effluent stream was monitored using a bromide ion-selective electrode, and samples were later analyzed in the laboratory by ion chromatography. The results of laboratory analyses are shown in Figure 5.1. The concentration profile in Figure 5.1 was integrated, and recovery of the center of mass of the tracer slug occurred after 120 min of pumping.

Effective porosity and seepage velocity were calculated using the following equations (Hall et al. 1990):

$$
n=\pi b x^{2} I^{2} T^{2} / Q t
$$

where $n$ = effective porosity

$b=$ aquifer thickness $(58 \mathrm{ft}$ )

$K=$ hydraulic conductivity $(45 \mathrm{ft} / \mathrm{d}$ ) 


$$
\sqrt{17}
$$




\subsection{POINT-DILUTION TEST}

The tracer injection for the drift-and-pumpback test was treated as a point-dilution test by monitoring bromide concentration in the well bore as a function of both time and depth. Downhole measurements were made using a $\mathrm{Ag} / \mathrm{AgBr}$ bromide ion-selective electrode and a platinum wire reference electrode. Measurements were made at $4-\mathrm{ft}$ intervals, from 27 to $79 \mathrm{ft}$ below the top of the well casing.

Analysis of the test results was based on the following equation (Kearl et al. 1988):

$$
v^{*}=-(v / a t) \ln \left(c / c_{0}\right)
$$

where $V^{*}=$ ground water flow velocity in the well bore

$v=$ volume of the segment of the well bore

$a=$ cross-sectional area of the segment of the well bore

$t=$ time

$C_{0}=$ initial tracer concentration

$C=$ tracer concentration at time $t$.

Actual seepage velocity, $V$, at a given depth is equal to the product of $V^{*}$, of the effective porosity of the formation at that depth, and of a correction factor that accounts for flow distortion caused by the well itself. The calculated velocity, $V^{*}$, is also proportional to the rate of flux (i.e., volume per unit time). For the present analysis, the correction factor is assumed to be invariant with depth.

The use of a platinum electrode in place of the preferred double-junction reference electrode rendered it difficult to measure absolute bromide concentrations. However, relative measurements (i.e., the proportional change in bromide concentration over time at any given depth) proved satisfactory. To use relative concentrations, Equation (5) was differentiated, with the following result:

$$
d(\operatorname{lnc}) / d t=-(a / v) v^{*}
$$


In Equation (6), the left-hand term is equal to the slope of a plot of $\operatorname{lnC}$ versus $t$, and $a / v$ is equal to 1.525 . Because the ordinate scale of the plot is logarithmic, constant proportional error in the measurement of $C$ does not affect the slope of the plot. Figure 6.1 illustrates typical plots for three depths.

Figure 6.2 shows a plot of relative horizontal flux as a function of depth, where individual values of $V^{*}$, calculated according to Equation (6), have been normalized to the highest value of $V^{*}$. The figure shows that transport of ground water decreases with depth. At $79 \mathrm{ft}$, no change was

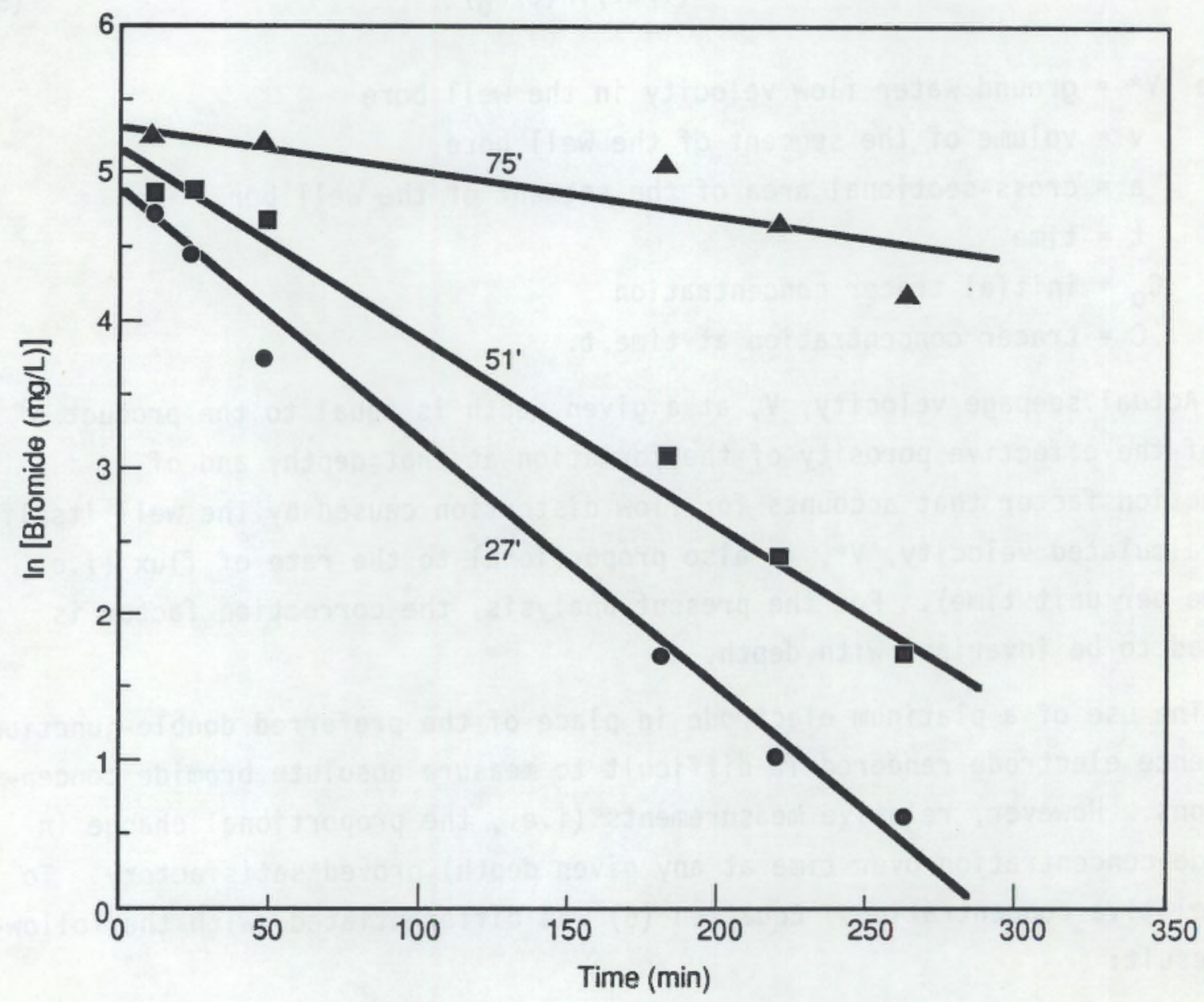

FIGURE 6.1. Bromide Concentration Versus Time During the PointDilution Test for Three Representative Depths 


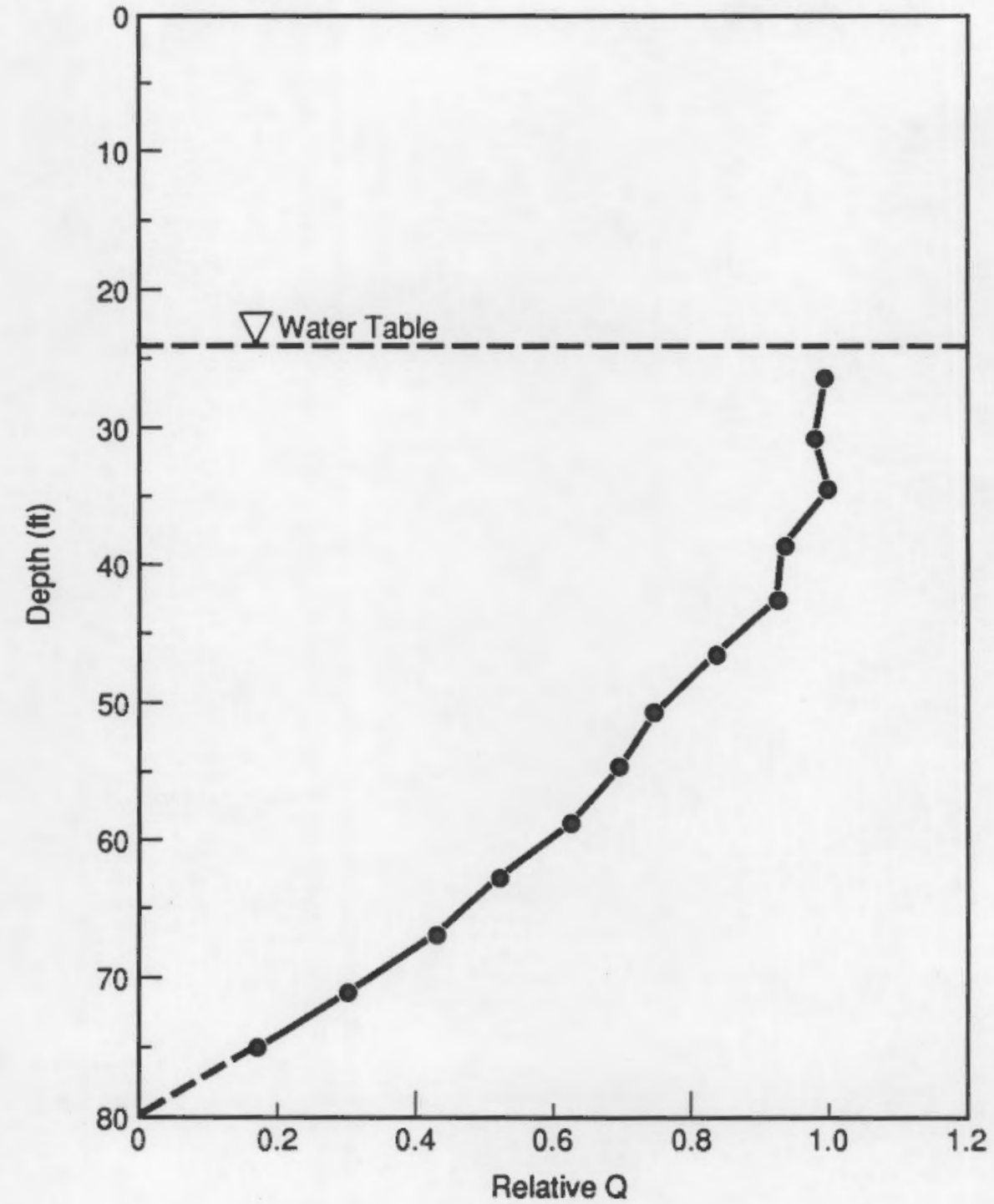

FIGURE 6.2. Relative Ground-Water Flow as a Function of Depth

discernible in the bromide concentration over the duration of the test, so ground-water flow at and below that level is small compared with the rest of the aquifer. Given the uncertainty of the measurements from the ion-selective electrode, the upper limit of the flow rate in the bottom $5 \mathrm{ft}$ of the aquifer is estimated to be no more than $10 \%$ of that of the upper $20 \mathrm{ft}$ of saturated sediments. 



\subsection{MULTI-WELL TRACER TEST}

On October 24, a multi-well tracer test conducted under natural gradient was initiated by injecting $124 \mathrm{~g}$ of lithium bromide into Well \#10. The injection technique was the same as described above for the drift-and-pumpback test. Immediately following tracer injection, 3400 gal of ground water from Well \#4 was pumped into Well \#10 at $225 \mathrm{gpm}$. This additional water was added to increase the horizontal dimension of the tracer slug. Wells $\# 1, \# 2, \# 3$, and $\# 4$, all of which are generally down-gradient from Well \#10, will be periodically sampled at depths of 30,50 , and $70 \mathrm{ft}$ to detect the arrival of the chemical tracer. Results of this experiment will be reported after testing is complete. 


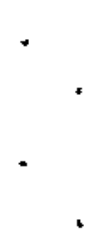

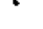




\subsection{DISCUSSION}

Iwo principal objectives of the testing at Well 10 were to determine the injection capacity of the aquifer and to examine the efficiency of the well design. Figure 3.3 shows that the rate of rise in water level in the well bore was a constant $0.060 \mathrm{ft} / \mathrm{gpm}$ when water was injected at a depth of $50 \mathrm{ft}$ (26 ft below static water level). Extrapolated to the top of the well casing, the maximum injection capacity is approximately $400 \mathrm{gpm}$. In contrast, injection of $225 \mathrm{gpm}$ with the pipeline terminating at the top of the well casing (as was done during the 3400-gal injection for the multi-well tracer test) resulted in air-entrapment and frothing, and the liquid level in the well bore was just below the top of the casing. That is, air-entrapment reduced injection capacity by nearly half.

Figure 3.3 also shows that the capacity of well to accept water at any given flow rate within the experimental range is nearly constant. At Well \#4, on the other hand, apparent well losses are significant (Figure 3.4), and well loss at $60 \mathrm{gpm}$ was used to correct observed specific capacity for the 60 -gpm tracer pumpback at Well $\# 10$. The use of this correction was based on the assumption that the apparent difference in well efficiency between the two wells was caused by different effective screen lengths during testing. During injection at Well 10, effective screen length was a constant $62 \mathrm{ft}$ during the entire test (see Figure 2.1). During withdrawal at Well 14 , effective screen length was reduced as pumping rate and drawdown increased. That is, well efficiency at Well \#10, during withdrawal, would be assumed to be similar to that at Well \#4.

However, it is possible that the efficiency of well \#10 is greater than that of well \#4. These wells were constructed similarly, but not necessarily identically. Also, inspection of Figure 6.2 shows that flow, and therefore the hydraulic conductivity of the aquifer, decreases with depth. Further, the compositional gradation of the sediments shown in Figure 2.1 is similar to that observed at Well \#4 (Luttrell et al. 1989). As drawdown increases, the effective hydraulic conductivity of the aquifer in the vicinity of the well bore will decrease, so a decrease in specific capacity is reasonably expected. 
Either of these possibilities suggests that the well-loss correction applied to the observed specific capacity for Well \#10 may be too large. With the well-loss correction, calculated transmissivity is $2600 \mathrm{ft}^{2} / \mathrm{d}$, hydraulic conductivity is $45 \mathrm{ft} / \mathrm{d}$, effective porosity is $8.0 \%$, and seepage velocity is $2.7 \mathrm{ft} / \mathrm{d}$. If the well loss is ignored, and Equations (2), (3) and (4) are re-applied, transmissivity is $2300 \mathrm{ft}^{2} / \mathrm{d}$, hydraulic conductivity is $40 \mathrm{ft} / \mathrm{d}$, effective porosity is $6.0 \%$, and velocity is $3.1 \mathrm{ft} / \mathrm{d}$. These latter values for conductivity, porosity, and velocity are very close to the parameters determined by Luttrell et al. (1989) for Well \#4.

The similarity of test results at Wells $\# 10$ and $\# 4$ is a strong indication that areal variability of hydraulic parameters within the proposed well field is small. This uniformity will simplify well field modeling and design. 


\subsection{REFERENCES}

Driscoll, F. G. 1986. Ground Water and Wells, 2nd Edition. Johnson Division, UoP Inc., St. Paul, Minnesota.

Hall, S. H., S. P. Luttrell, and W. E. Cronin. 1990. A Method for Estimating Effective Porosity and Ground-Water Velocity. PNL-SA-17797, Pacific Northwest Laboratory, Richland, Washington.

Jacob, C. E. 1946. "Drawdown Test to Determine Effective Radius of Artesian We11." Trans. Am. Soc. Civ. Eng. 112:1047-1070.

Kearl, P. M., J. J. Dexter, and J. E. Price. 1988. Procedures, Analysis, and Comparison of Groundwater Velocity Measurement Methods for Unconfined Aquifers. UNC/GJ-TMC-3, UNC Geotech, Grand Junction, Colorado.

Leap, D. I., and P. G. Kaplan. 1988. "A Single-We11 Tracing Method for Estimating Regional Advective Velocity in a Confined Aquifer: Theory and Preliminary Laboratory Verification." Water Res. Res. 23(7):993-998.

Luttrell, S. P., W. E. Cronin, and S. H. Ha]l. 1989. Aquifer Characterization at the General Motors Harrison Division Plant, Tuscaloosa, Alabama.

PNL-7141, Pacific Northwest Laboratory, Richland, Washington.

Walton, W. C. 1970. Groundwater Resource Evaluation. McGraw-Hill, New York. 
. 


\section{DISTRIBUTION}

No. of

Copies

OFFSITE

12 DOE/Office of Scientific and Technical Information

University of Alabama

Attn: C. E. Brett

Bureau of Engineering Research

Box 870201

Tuscaloosa, AL 35487-0201

University of Alabama

Attn: Clark Midkiff

Dept. of Mechanical

Engineering

Box 870276

Tuscaloosa, AL 35487-0276

University of Alabama

Attn: Kannan Balaji

Dept. of Mechanical

Engineering

Box 870276

Tuscaloosa, AL 35487-0276

U.S. Department of Energy

Attn: R. Eaton

Office of Energy Management

Forrestal Bldg., CE-142 5E-036

Washington, DC 20585

U.S. Department of Energy

Attn: K. W. KTunder

Office of Energy Managenent

Forrestal Bldg., CE-142 5E-036

Washington, OC 20585

U.S. Department of Energy

Attn: E. Reimers

Office of Energy Managenent

Forrestal Bldg., CE-142 5E-036

Washington, DC 20585
No. of

Copies

Auburn University

Attn: P. J. Molz

Schoot of Engineering

Auburn, AL 36830

Lawrence Berkeley Laboratory

Attn: $C-F$, Tsang

University of California

Bldg. 90, Room 1012-H

1 Cyclotron Road

Berkeley, CA 94720

New York State Energy Research

Development Agency

Attn: $G$. Walmet

Rockefeller Plaza

Albany, NY 12223

Oak Ridge National Laboratory

Attn: J. Tonlinson

Building 9204-1, MS 8045

$Y-12$ Plant, Box 2009

0ak Ridge, TN 37831-8045

U.S. Department of Interior

Attn: Natural Resources

Library

Serial Branch (G/E)

Washington, DC 20240

Wehran Engineering

Attn: R. Miller

666 E. Main St.

P.0. Box 2006

Middletown, NY 10940

Wilke and Assocjates

Attn: D. Wilke

38 Roosevelt Avenue

Glen Head, NY 11545 
No. of

Copies

Public Works Canada .

Attn: E. L. Morofsky

C456 Sir Charles Tupper Bldg.

Riverside Dr. and Heron Rd.

Ottawa, Ontario

K1A 0M2 Canada

\section{ONSITE}

DOE Richland Operations Office

R. B. Goranson

43 Pacific Northwest Laboratory

M. P. Bergeron, K6-77

R. W. Bryce, K6-96

P. G. Doctor, K6-96

J. W. Falco, K6-78
No. of

Copies

J. M. Hales, K6-04

S. H. Ha11, K6-96 (5)

P. C. Hays, K6-86

R. E. Jarnagin, K5-20

L. D. Kannberg, K5-21

S. P. Luttre 11, K6-96

D. R. Newcomer, K6-96

W. T. Penne 11, K6-08

J. R. Raymond, K6-77

R. L. Skaggs, K6-77

J. L. Smoot, K6-77

L. W. Vail, K6-77

R. W. Wallace, K6-77

Publishing Coordination

Technical Report Files (5) 